\title{
Soil Application of SAR Inducers Imidacloprid, Thiamethoxam, and Acibenzolar-S-Methyl for Citrus Canker Control in Young Grapefruit Trees
}

\author{
James H. Graham and Monty E. Myers, University of Florida, IFAS, Soil and Water Science Department, Citrus Research and Educa-
} tion Center, Lake Alfred 33850

\begin{abstract}
Graham, J. H., and Myers, M. E. 2011. Soil application of SAR inducers imidacloprid, thiamethoxam, and acibenzolar-S-methyl for citrus canker control in young grapefruit trees. Plant Dis. 95:725-728.

Soil applications of inducers of systemic acquired resistance (SAR) imidacloprid, thiamethoxam, or acibenzolar- $S$-methyl, at various rates and application frequencies, were evaluated for control of citrus canker caused by Xanthomonas citri subsp. citri in a field trial of 3- and 4year-old 'Ray Ruby' grapefruit trees in southeastern Florida. Reduction of foliar incidence of canker produced by one, two, or four soil applications of imidacloprid, thiamethoxam, and acibenzolar- $S$-methyl was compared with 11 foliar sprays of copper hydroxide and streptomycin applied at 21-day intervals. In the 2008 and 2009 crop seasons, canker incidence on each set of vegetative flushes was assessed as the percentage of the total leaves with lesions. By the end of the 2008 season, despite above-average rainfall and a tropical storm event, all treatments significantly reduced foliar incidence of citrus canker on the combined spring-summer-fall flushes. Sprays of copper hydroxide

and streptomycin were effective for reducing canker incidence on shoot flushes produced throughout the season compared with the untreated control, whereas soil-applied SAR inducers reduced foliar disease depending on rate, frequency, and timing of application. Except for the treatment of four applications of acibenzolar-S-methyl at $0.2 \mathrm{~g}$ a.i. per tree or two applications of imidacloprid, SAR inducers were ineffective for reducing foliar disease on the flushes that were present during the tropical storm. In 2009, all treatments significantly reduced the incidence of foliar canker on the combined spring-summer-fall flushes but not all treatments of spring-summer flushes with SAR inducers were effective compared with the untreated control. Hence, depending on rate, frequency, and timing of application, soil-applied SAR inducers reduced incidence of canker on foliar flushes of young grapefruit trees under epidemic conditions.
\end{abstract}

Asiatic citrus canker, caused by the bacterial pathogen Xanthomonas citri subsp. citri (syn. X. axonopodis pv. citri), is a serious disease of commercial citrus cultivars and some citrus relatives (13). The pathogen causes distinctive necrotic, erumpent lesions on leaves, stems, and fruit. Severe infections can cause a range of symptoms from defoliation, blemished fruit, premature fruit drop, and twig dieback to general tree decline. Grapefruit (Citrus paradisi Macf.) is the most important fresh fruit citrus grown in Florida and the citrus cultivar most susceptible to canker (16). Canker has become endemic in grapefruit groves since a state-federal eradication program ended in January 2006 (11).

There are no highly effective canker disease suppression tactics for susceptible cultivars of citrus when the crop is grown in wet subtropical areas like Florida $(18,19,26)$. Copper reduces bacterial populations on leaf surfaces but multiple applications are needed to achieve adequate control on susceptible citrus hosts $(20,27,28)$. The protective activity of copper is diminished by wind-blown rain that introduces bacteria directly into stomata $(10,12)$. Therefore, copper is used in conjunction with windbreaks in South America under weather conditions similar to those in Florida $(3,16,19)$. Disadvantages for long-term use of copper bactericides include the selection for copper resistance in xanthomonad populations $(4,22,25)$ and accumulation of copper in citrus soils with potential phytotoxic and adverse environmental effects (1). However, other contact bactericides are not as effective as copper because they lack sufficient residual activity to protect leaf and fruit surfaces for extended periods $(16,20,23,26,31)$.

Systemic acquired resistance (SAR) is an innate plant defense that may confer long-lasting protection against a broad spectrum of

Corresponding author: J. H. Graham, E-mail: jhgraham@ufl.edu

Accepted for publication 15 February 2011.

doi:10.1094/PDIS-09-10-0653

(C) 2011 The American Phytopathological Society microorganisms $(6,33)$. Plants acquire an enhanced defensive capacity against subsequent pathogen attack as a result of induction by primary, limited pathogen infection. SAR requires the signal molecule salicylic acid (SA) and is associated with the accumulation of pathogenesis-related (PR) proteins, which are thought to contribute to resistance. SAR may be activated in the absence of pathogens by treatment of plants with chemical inducers (9). Acibenzolar-S-methyl (ASM; Actigard or Bion; Syngenta Crop Protection), a functional homolog of SA, is the most widely known commercially produced inducer of SAR (30).

ASM and other commercial inducers of resistance have been extensively evaluated as components for plant disease control in the field (32); however, their effectiveness for practical application in disease management has been questioned due to variability of control (34). Field studies showing promise for control of bacterial diseases have been conducted with foliar sprays of ASM either alone or in combination with copper on tomato and pepper $(21,24)$. For citrus, foliar application of ASM was effective against citrus canker under greenhouse conditions but foliar sprays of ASM combined or alternated with copper oxychloride did not contribute to control of canker on sweet orange trees in field trials (14). Expression of the PR protein ( $\beta-1,3$ glucanase) gene, PR-2, in citrus increased in response to ASM and isonicotinic acid (INA). However, PR-2 response and reduction of lesions after foliar sprays was sustained for only a few weeks (5). Likewise, ASM induced acidic PR-1 expression in tomato for 7 to 10 days (17), confirming why foliar applications at weekly intervals are required for field control of Xanthomonas leaf spot and Pseudomonas bacterial speck on tomato (21).

Soil application of the neonicotinoid imidacloprid (IMID) involves the use of this insecticide for citrus bacterial disease management through the control of the interaction of citrus leafminer (Phyllocnistis citrella) with X. citri subsp. citri or X. alfalfae pv. citrumelonis, the cause of citrus bacterial spot in Florida citrus nurseries $(15,28)$. Reduction in the incidence of foliar lesions for weeks was not due to the prevention of exacerbation of citrus bacterial spot by leafminer because foliar insecticides were applied 
to control leafminer damage $(15,28)$. Likewise, incidence of canker lesions on foliage of young sweet orange trees in the field was suppressed for months in Brazil, where foliar insecticides were applied to control leafminer (15). IMID breaks down in planta into 6-chloronicotinic acid, an analog of INA which induces SAR response $(2,7,29)$. In a greenhouse pot trial, Francis et al. (8) confirmed that soil drenches of IMID as well as INA and ASM induced a high and persistent upregulation of PR-2 gene expression that was correlated with reduction of canker lesions for up to 24 weeks compared with 4 weeks for inoculated plants sprayed with ASM. Canker lesions on leaves of SAR-treated citrus seedlings were small, necrotic, and flat compared with pustular lesions on untreated inoculated plants. Population of $X$. citri subsp. citri per leaf was reduced 1 to $3 \log$ units in plants treated with soil applications of ASM compared with untreated plants (8).

The purpose of this research was to validate the efficacy of soilapplied SARs for control of canker lesion development under citrus canker epidemic conditions in young grapefruit trees in southeastern Florida. In this study, we evaluated soil drenches of IMID, ASM, and INA for control of citrus canker on the foliage. Thiamethoxam (THIA), another soil-applied neonicotinoid widely used for insect control in Florida citrus, was also included for comparison.

\section{Materials and Methods}

Field site and treatments. In 2008, a field trial was conducted with 3-year-old nonbearing 'Ray Ruby' grapefruit trees planted in 2005 at Ft. Pierce, St. Lucie County, FL. Treatments were arranged in a randomized complete block design with 13 treatments replicated five times in blocks of five contiguous trees. Three foliar treatments were copper hydroxide at $0.57 \mathrm{~g}$ a.i. per tree per application (CH; Kocide 3000; 30\% metallic $\mathrm{Cu}$ a.i.; DuPont), streptomycin at $0.80 \mathrm{~g}$ a.i. per tree per application (STREP; FireWall 17WP; $17 \%$ a.i.; Agrosource, Inc.), and a mixture of $\mathrm{CH}$ and STREP at the same rates. Soil-applied treatments consisted of
ASM (Actigard 50WG; 50\% a.i.; Syngenta Crop Protection) at 0.1 and $0.2 \mathrm{~g}$ a.i. per tree in two or four applications, IMID (Admire Pro, $42.8 \%$ a.i.; Bayer Crop Science) at $1.48 \mathrm{~g}$ a.i. per tree in one application or $0.74 \mathrm{~g}$ a.i. per tree in two applications, THIA (Platinum, $21.6 \%$ a.i.; Syngenta Crop Protection) at $0.5 \mathrm{~g}$ a.i. per tree in one application or $0.25 \mathrm{~g}$ a.i. per tree in two applications, and INA at $1.9 \mathrm{~g}$ a.i per tree in one application. One treatment included a single soil application of IMID at $1.48 \mathrm{~g}$ a.i. per tree at the beginning of the season followed by $\mathrm{CH}$ sprays. The untreated control (UTC) trees received a water-only spray treatment at each foliar spray time. Products were mixed with water and applied as foliar sprays at 3.0 liters/tree with a handgun sprayer at $1,380 \mathrm{kPa}$ of air pressure or applied as a soil drench at 0.230 liters/tree to the soil surface in a crescent within 10 to $15 \mathrm{~cm}$ of the trunk on the top side of the bed to minimize runoff. To facilitate infiltration, microsprinkler irrigation was applied for a few minutes to prewet the soil surface before drenching. The materials, application rates, and number and dates of application for each treatment are listed in Table 1. For the combination treatment of $\mathrm{CH}$ and STREP, the two materials were tank mixed prior to spray application. Treatments were initiated after the spring flush in March 2008. Foliar applications of the insecticides abamectin, fenpropathrin, and dimethoate were applied through the season to protect new flush leaves from citrus leafminer damage to minimize the interaction with $X$. citri subsp. citri (28).

In 2009, the treatments were repeated in the same plot locations as for the 2008 trial with 4-year-old trees. The treatments were the same as in 2008, with the addition of a treatment with two applications of THIA (Table 1). Treatment application dates for 2009 are listed in Table 1.

Monthly rainfall in 2008 and 2009 was recorded at the nearby University of Florida/IFAS, Indian River Research and Education Center, Ft. Pierce and compared with the average for the last 10 years (Table 2).

Table 1. Treatments applied to 3- and 4-year-old 'Ray Ruby' grapefruit trees at Ft. Pierce, FL in 2008 and 2009

\begin{tabular}{|c|c|c|c|c|}
\hline \multirow[b]{2}{*}{ Treatment $^{\mathrm{x}}$} & \multicolumn{2}{|c|}{ Applications } & \multicolumn{2}{|c|}{ Application dates } \\
\hline & Number ${ }^{y}$ & Rate $(\mathrm{g} \text { a.i. })^{\mathrm{z}}$ & 2008 & 2009 \\
\hline UTC & $\ldots$ & & $\ldots$ & $\ldots$ \\
\hline ASM & 2 & 0.1 & $3 / 3,6 / 6$ & $3 / 18,6 / 15$ \\
\hline ASM & 2 & 0.2 & $3 / 3,6 / 6$ & $3 / 18,6 / 15$ \\
\hline ASM & 4 & 0.1 & $3 / 3,5 / 7,7 / 7,9 / 8$ & $3 / 18,5 / 13,7 / 15,9 / 16$ \\
\hline ASM & 4 & 0.2 & $3 / 3,5 / 7,7 / 7,9 / 8$ & $3 / 18,5 / 13,7 / 15,9 / 16$ \\
\hline IMID & 1 & 1.48 & $3 / 3$ & $3 / 18$ \\
\hline IMID & 2 & 0.74 & $3 / 3,7 / 7$ & $3 / 18,7 / 15$ \\
\hline INA & 1 & 1.9 & $3 / 3$ & $3 / 18$ \\
\hline THIA & 1 & 0.50 & $3 / 3$ & $3 / 18$ \\
\hline THIA & 2 & 0.25 & Not treated in 2008 & $3 / 18,7 / 15$ \\
\hline $\mathrm{CH}$ & 11 & 0.57 & $\begin{array}{l}3 / 7,3 / 28,4 / 18,5 / 9,5 / 30,6 / 20,7 / 11,8 / 4,8 / 26,9 / 15 \\
10 / 6\end{array}$ & $\begin{array}{l}3 / 23,4 / 13,5 / 4,5 / 26,6 / 15,7 / 7,7 / 27,8 / 17,9 / 8,9 / 29 \\
10 / 13\end{array}$ \\
\hline STREP & 11 & 0.80 & $\begin{array}{l}3 / 7,3 / 28,4 / 18,5 / 9,5 / 30,6 / 20,7 / 11,8 / 4,8 / 26,9 / 15 \\
10 / 6\end{array}$ & $\begin{array}{l}3 / 23,4 / 13,5 / 4,5 / 26,6 / 15,7 / 7,7 / 27,8 / 17,9 / 8,9 / 29, \\
10 / 13\end{array}$ \\
\hline STREP/CH & 11 & $0.80 / 0.57$ & $\begin{array}{l}3 / 7,3 / 28,4 / 18,5 / 9,5 / 30,6 / 20,7 / 1,8 / 4,8 / 26,9 / 15 \\
10 / 6\end{array}$ & $\begin{array}{l}3 / 23,4 / 13,5 / 4,5 / 26,6 / 15,7 / 7,7 / 27,8 / 17,9 / 8,9 / 29 \\
10 / 13\end{array}$ \\
\hline IMID/CH & $1 / 11$ & $1.48 / 0.57$ & $\begin{array}{l}3 / 3 \text { (IMID) } 3 / 7,3 / 28,4 / 18,5 / 9,5 / 30,6 / 20,7 / 11,8 / 4, \\
8 / 26,9 / 15,10 / 6\end{array}$ & $\begin{array}{l}3 / 18 \text { (IMID) } 3 / 23,4 / 13,5 / 4,5 / 26,6 / 15,7 / 7,7 / 27,8 / 17 \text {, } \\
9 / 8,9 / 29,10 / 13\end{array}$ \\
\hline
\end{tabular}

${ }^{\mathrm{x}} \mathrm{UTC}=$ untreated control, ASM = acibenzolar-S-methyl, IMID = imidacloprid, INA = isonicotinic acid, THIA = thiamethoxam, $\mathrm{CH}=$ copper hydroxide, and STREP = streptomycin.

${ }^{\mathrm{y}}$ Number of applications.

${ }^{\mathrm{z}}$ Amount of treatment per tree per application.

Table 2. Rainfall at Ft. Pierce, FL in 2008 and 2009

\begin{tabular}{lccrcccrrr}
\hline & \multicolumn{10}{c}{ Monthly rainfall (mm) } \\
\cline { 2 - 9 } Year & March & April & May & June & July & August & September & October & November \\
\hline 2008 & 66 & 0.7 & 88 & 8.6 & 219 & 429 & 117 & 121 & 29 \\
2009 & 52 & 11 & 223 & 83 & 189 & 189 & 42 & 28 & 7 \\
Average $^{z}$ & 50 & 64 & 76 & 166 & 186 & 159 & 158 & 101 & 53 \\
\hline
\end{tabular}

${ }^{\text {z }}$ Average monthly rainfall from 1998 to 2008 obtained from Florida Automated Weather Network at Indian River Research and Education Center, Ft. Pierce. 
Disease evaluation. In 2008, disease on foliage was assessed as the percentage of canker-infected leaves on sets of leaf flushes: spring-first summer, spring-summer, and spring-summer-fall in June, October, and December, respectively. Canker incidence on each set of flushes was expressed as the percentage of the total number of leaves with canker lesions. In 2009, the number of canker-diseased leaves on flushes in spring-first summer, spring-summer, and spring-summer-fall was assessed in June, September, and November, respectively.

Statistical analysis. Data for incidence of diseased leaves were log-transformed and subjected to a three-way analysis of variance (ANOVA) to evaluate the main effects and interactions of trial year, disease evaluation time and chemical treatment using PROC GLM (SAS Institute). This analysis detected a significant year-treatment and evaluation time-treatment interaction. Therefore, a one-way ANOVA was performed and the treatment means were separated using Waller-Duncan multiple range test at $P<0.05$.

\section{Results}

2008 trial. The rainfall until July was below average compared with the last 10 years (Table 2). All treatments significantly reduced incidence of canker on the spring-first summer flushes compared with the UTC (Table 3). On 20 to 22 August, 3 days of sustained windblown rain from Tropical Storm Fay increased canker incidence on the spring-summer flushes to levels 2.5 to 7 times higher than that observed on the earlier flushes with the same treatments (Table 3). Incidence of foliar canker on shoot flushes present during this period was reduced by foliar sprays of $\mathrm{CH}$, STREP, and the combination of STREP with $\mathrm{CH}$ compared with the UTC. Among the soil-applied SAR inducers, only the treatments of four applications of ASM at $0.2 \mathrm{~g}$ a.i. or two applications of IMID significantly reduced foliar disease on the spring-summer flushes. On the spring-summer-fall flushes, canker incidence was significantly lower for all treatments compared with the UTC (Table 3). Disease control on trees sprayed 11 times with $\mathrm{CH}$ was significantly greater than for SAR treatments, except compared with four applications of $0.2 \mathrm{~g}$ of ASM. The disease incidence on the spring-summer-fall flushes for this soil-applied treatment was also statistically comparable with the other foliar treatments.

2009 trial. Despite above-average rainfall in May (Table 2), the spring-first summer flush was free of canker lesions in all treatments (Table 3). In contrast, untreated spring-summer flushes evaluated in September had $62 \%$ canker-diseased leaves. Foliar sprays of $\mathrm{CH}$ and IMID significantly reduced canker incidence on spring-summer flushes, whereas only SAR treatments of four applications of ASM at $0.2 \mathrm{~g}$ a.i., two applications of THIA, or one and two applications of IMID reduced foliar disease compared with the UTC. On the spring-summer-fall flushes, all treatments significantly reduced foliar disease compared with the UTC.

\section{Discussion}

Depending on rate, frequency, and timing of application, soil application of the SAR inducers IMID, THIA, and ASM reduced incidence of canker on foliar flushes of young grapefruit trees under epidemic conditions. During the period of highest disease pressure on the summer flushes, soil-applied SAR inducers failed to reduce foliar disease whereas effective disease control was maintained with foliar sprays of copper or streptomycin $(3,16)$. However, by the end of each season, lower canker incidence on trees treated with SAR inducers was attained with one to four soil applications compared with 11 sprays of bactericides applied at a 21day interval (13). Reduction of canker lesion incidence in the field by SAR inducers was predicted from greenhouse studies demonstrating a high level of control for up to 24 weeks compared with 4 weeks post application for foliar ASM (8). In previous field studies of tomato and pepper, foliar ASM was applied at weekly intervals for season-long control of bacterial leaf spots $(21,24)$. In contrast, six sprays of foliar-applied ASM combined with copper failed to provide additional control of canker on sweet orange leaves and fruit compared with copper alone (14).

In contrast to the failure of foliar-applied ASM to reduce canker in previous greenhouse and field studies $(5,14)$, soil-applied ASM was effective for reducing foliar disease incidence during seasonal canker epidemics, as demonstrated with artificially inoculated citrus plants (8). The longevity of activity produced by soil application may be attributed to gradual release and uptake of ASM into the roots, and the progressive translocation from root to actively growing shoots as previously demonstrated for IMID (29). Sustained supply of chemical inducers to expanding susceptible leaves may be further promoted through periodic soil applications, as demonstrated by the disease control effect of four applications of ASM at $0.2 \mathrm{~g}$ a.i. on spring-summer flushes in 2008 and 2009. Although the effectiveness of soil-applied SAR inducers was reduced by Tropical Storm Fay in 2008 and during the wetter conditions in summer of 2009, SAR inducers reduced disease incidence on the fall leaf flush that emerged after this period. An inoculum control effect of ASM, IMID, or INA is supported by the previous finding that, post infection, lesions on potted seedlings treated with soil drenches had 1 to $3 \log$ units fewer bacteria than lesions from untreated plants (8).

Intense use of foliar-applied ASM can result in reduction in growth and yield of tomato and pepper $(21,24)$, a phenomenon referred to as "yield drag". In greenhouse trials with citrus, ASM caused mild leaf chlorosis but the symptoms were temporary (8)

Table 3. Comparison of soil-applied systemic-acquired resistance treatments with contact spray treatments on the percentage of canker-infected leaves for three sets of flushes on 3- and 4-year-old 'Ray Ruby' grapefruit tree at Ft. Pierce, FL in 2008 and 2009y

\begin{tabular}{|c|c|c|c|c|c|c|c|}
\hline \multirow[b]{2}{*}{ Treatment $^{\mathrm{z}}$} & \multirow[b]{2}{*}{ Applications } & \multicolumn{2}{|c|}{ Spring-first summer flushes (\%) } & \multicolumn{2}{|c|}{ Spring-summer flushes $(\%)$} & \multicolumn{2}{|c|}{ Spring-summer-fall flushes (\%) } \\
\hline & & 2008 & 2009 & 2008 & 2009 & 2008 & 2009 \\
\hline UTC & & $34.1 \mathrm{a}$ & 0.0 & $84.7 \mathrm{a}$ & $61.5 \mathrm{a}$ & $70.4 \mathrm{a}$ & $71.7 \mathrm{a}$ \\
\hline ASM $0.1 \mathrm{~g}$ & 2 & $15.4 \mathrm{bc}$ & 0.0 & $62.6 \mathrm{abcd}$ & $27.4 \mathrm{bc}$ & $43.6 \mathrm{~b}$ & $31.2 \mathrm{bcd}$ \\
\hline ASM $0.2 \mathrm{~g}$ & 2 & $17.5 \mathrm{bc}$ & 0.0 & $59.6 \mathrm{abcd}$ & $35.2 \mathrm{abc}$ & $47.8 \mathrm{~b}$ & $34.1 \mathrm{bcd}$ \\
\hline ASM $0.1 \mathrm{~g}$ & 4 & $18.3 \mathrm{~b}$ & 0.0 & $55.7 \mathrm{abcd}$ & $47.8 \mathrm{ab}$ & $33.6 \mathrm{bcd}$ & $46.6 \mathrm{~b}$ \\
\hline ASM $0.2 \mathrm{~g}$ & 4 & $8.7 \mathrm{bc}$ & 0.0 & 46.8 bcde & $15.8 \mathrm{bc}$ & $22.1 \mathrm{cde}$ & $12.8 \mathrm{~cd}$ \\
\hline IMID & 1 & $11.9 \mathrm{bc}$ & 0.0 & $69.7 \mathrm{abc}$ & $29.5 \mathrm{bc}$ & $46.2 \mathrm{~b}$ & $28.1 \mathrm{bcd}$ \\
\hline IMID & 2 & $13.0 \mathrm{bc}$ & 0.0 & 44.4 bcde & $21.1 \mathrm{bc}$ & $38.2 \mathrm{bc}$ & $20.8 \mathrm{~cd}$ \\
\hline INA & 1 & $10.9 \mathrm{bc}$ & 0.0 & $59.2 \mathrm{abcd}$ & $34.8 \mathrm{abc}$ & $36.1 \mathrm{bcd}$ & $38.7 \mathrm{bc}$ \\
\hline THIA & 1 & $10.7 \mathrm{bc}$ & 0.0 & $76.7 \mathrm{ab}$ & $19.1 \mathrm{bc}$ & $35.8 \mathrm{bcd}$ & $18.1 \mathrm{~cd}$ \\
\hline THIA & 2 & NT & 0.0 & NT & $38.6 \mathrm{abc}$ & NT & $36.3 \mathrm{bcd}$ \\
\hline $\mathrm{CH}$ & 11 & $4.8 \mathrm{c}$ & 0.0 & $15.2 \mathrm{e}$ & $22.8 \mathrm{bc}$ & $12.2 \mathrm{e}$ & $15.1 \mathrm{~cd}$ \\
\hline STREP & 11 & $9.4 \mathrm{bc}$ & 0.0 & $34.9 \mathrm{cde}$ & $11.8 \mathrm{c}$ & $18.2 \mathrm{de}$ & $11.1 \mathrm{~d}$ \\
\hline STREP/CH & 11 & $7.6 \mathrm{bc}$ & 0.0 & $27.9 \mathrm{de}$ & $15.1 \mathrm{bc}$ & 28.0 bcde & $13.6 \mathrm{~cd}$ \\
\hline IMID/CH & $1 / 11$ & $5.2 \mathrm{c}$ & 0.0 & $34.9 \mathrm{cde}$ & $9.0 \mathrm{c}$ & 27.8 bcde & $10.0 \mathrm{~d}$ \\
\hline
\end{tabular}

${ }^{y}$ Flushes were evaluated in June, October, and December in 2008 and June, September, and November in 2009. Values are the means of five replicate plots of five trees. Different letters indicate significant differences at $P<0.05 \%$ according to Waller-Duncan multiple range test; NT $=$ not treated in 2008 .

${ }^{\mathrm{z}} \mathrm{UTC}=$ untreated control, ASM $=$ acibenzolar-S-methyl, IMID $=$ imidacloprid, INA $=$ isonicotinic acid, THIA $=$ thiamethoxam, $\mathrm{CH}=$ copper hydroxide, and STREP = streptomycin. 
and no such symptoms were observed in the field trials. Stunting and yield reductions in certain plant species and cultivars have been attributed to the physiological cost of constitutive induction of plant defense (34). To optimize the use of SAR and to avoid phytotoxicity, the rate or frequency of SAR applications have been reduced or integrated with other bactericides such as copper (24). In this study, somewhat greater (though not significant) canker control was observed in the 2009 trial by combining the systemic control activity from a single soil application of IMID with contact activity of $\mathrm{CH}$. This suggests that integration of systemic with contact activity may be more effective for protection of leaves from infection, as previously demonstrated (24).

Copper-resistant strains of $X$. citri subsp. citri have been identified in citrus groves in Argentina (4). Louws et al. (21) demonstrated that ASM is particularly useful for disease management of bacterial speck and bacterial spot where copper-resistant strains predominated. Therefore, soil-applied SAR inducers could be employed for copper-resistance management by reducing the rate and frequency of copper bactericide applications for highly susceptible young trees.

\section{Acknowledgments}

This research was supported by a grant from the Florida Citrus Research and Development Foundation and funding from Syngenta Crop Protection and Bayer Crop Science.

\section{Literature Cited}

1. Alva, A. K., Graham, J. H., and Anderson, C. A. 1995. Soil pH and copper effects on young 'Hamlin' orange trees. Soil Sci. Soc. Am. J. 59:481-487.

2. Beckers, G. J., and Conrath, U. 2007. Priming for stress resistance: from the lab to the field. Curr. Opin. Plant Biol. 10:425-431.

3. Behlau, F., Belasque, J., Jr., Graham, J. H., Leite, R. P., Jr. 2009. Effect of frequency of copper applications on control of citrus canker and the yield of young bearing sweet orange trees. Crop Prot. 29:300-305.

4. Canteros, B. I., Rybak, M., Gochez, A., Velazquez, P., Rivadeneira, M., Mitidieri, M., Garran, S., and Zequeira, L. 2008. Occurrence of copper resistance in Xanthomonas axonopodis pv. citri in Argentina. (Abstr.) Phytopathology 98:S30.

5. Dekkers, M. G. H., Graham, J. H., Burns, J. K., Cubero, J., and Colburn, G. C. 2004. Evaluation of chemical inducers and PR protein reporters for induced systemic resistance to citrus bacterial diseases. (Abstr.) Phytopathology 94:S25.

6. Durrant, W. E., and Dong, X. 2004. Systemic acquired resistance. Annu. Rev. Phytopathol. 42:185-209.

7. Ford, K. A., Casida, J. E., Chandran, D., Gulevicha, A. G., Okrent, R. A., Durkinc, K. A., Sarpong, R., Bunnellec, E. M., and Wildermuth, M. C. 2010. Neonicotinoid insecticides induce salicylate associated plant defense responses. Proc. Nat. Acad. Sci. USA 107:17527-17532.

8. Francis, M. I., Redondo, A., Burns, J. K., and Graham, J. H. 2009. Soil application of imidacloprid and related SAR inducing compounds produces effective and persistent control of citrus canker. Eur. J. Plant Pathol. 124:283-292.

9. Gorlach, J., Volrath, S., Knauf-Beiter, G., Hengy, G., Beckhove, U., Kogel, K.-H., Oostendorp, M., Staub, T., Ward, E., Kessmann, H., and Ryals, J. 1996. Benzathiadiazole, a novel class of inducers of systemic acquired resistance, activates gene expression and disease resistance in wheat. Plant Cell 8:629-643.

10. Gottwald, T. R., and Graham, J. H. 1992. A device for precise and nondisruptive stomatal inoculation of leaf tissue with bacterial pathogens. Phytopathology 82:930-935

11. Gottwald, T. R., and Irey, M. 2007. Post-hurricane analysis of citrus canker II: Predictive model estimation of disease spread and area potentially impacted by various eradication protocols following catastrophic weather events. Plant Health Progress. Online. doi:10.1094/PHP-2007-0405-01-RS.
12. Gottwald, T. R., and Timmer, L. W. 1995. The efficacy of windbreaks in reducing the spread of citrus canker caused by Xanthomonas campestris $\mathrm{pv}$ citri. Trop. Agric.72:194-201.

13. Graham, J. H., Gottwald, T. R., Cubero, J., and Achor, D. S. 2004. Xan thomonas axonopodis pv. citri: factors affecting successful eradication of citrus canker. Mol. Plant Pathol. 5:1-15.

14. Graham, J. H., and Leite, R. P. 2004. Lack of control of citrus canker by induced systemic resistance compounds. Plant Dis. 88:745-750.

15. Graham, J. H., and Leite, R. P., Jr. 2007. Soil-applied neonicotinoids for control of bacterial diseases on young citrus trees. In: Proc. Int. Workshop PR-Proteins and Induced Resistance Against Pathogens and Insects. Doorn, The Netherlands.

16. Graham, J. H., Yonce, H. D., and Myers, M. 2008. Streptomycin controls citrus canker on sweet orange in Brazil and reduces risk of copper burn on grapefruit in Florida. Proc. Fla. State Hortic. Soc. 121:118-123.

17. Herman, M. A. B., Restrepo1, S., and Smart, C. D. 2007. Defense gene expression patterns of three SAR-induced tomato cultivars in the field. Physiol. Mol. Plant Pathol. 71:192-200.

18. Kuhara, S. 1978. Present epidemic status and control of the citrus canker disease (Xanthomonas citri (Hasse) Dowson) in Japan. Rev. Plant Prot. Res. 11:132-142.

19. Leite, R. P., Jr., and Mohan, S. K. 1990. Integrated management of the citrus bacterial canker disease caused by Xanthomonas campestris pv. citri in the State of Paraná, Brazil. Crop Prot. 9:3-7.

20. Leite, R. P., Jr., Mohan, S. K., Pereira, A. L. G., and Campacci, C. A. 1987. Integrated control of citrus canker: effect of genetic resistance and application of bactericides. Fitopatol. Bras. 12:257-263.

21. Louws, F. J., Wilson, M., Campbell, H. L., Cuppels, D. A., Jones, J. B., Shoemaker, P. B., Sahin, F., and Miller, S. A. 2001. Field control of bacterial spot and bacterial speck of tomato using a plant activator. Plant Dis. 85:481-488.

22. Marco, G. M., and Stall, R. E. 1983. Control of bacterial spot of pepper initiated by strains of Xanthomonas campestris pv. vesicatoria that differ in sensitivity to copper. Plant Dis. 67:779-781.

23. McGuire, R. G. 1988. Evaluation of bactericidal chemicals for control of Xanthomonas on citrus. Plant Dis. 72:1016-1020.

24. Romero, A. M., Kousik, C. S., and Ritchie, D. F. 2001. Resistance to bacterial spot in bell pepper induced by acibenzolar- $S$-methyl. Plant Dis. 85:189194.

25. Rinaldi, D. A. M. F., and Leite, R. P., Jr. 2000. Adaptation of Xanthomonas axonopodis pv. citri population to the presence of copper compounds in nature. Proc. Int. Soc. Citric. 2:1064.

26. Stall, R. E., Miller, J. W., Marco, G. M., and Canteros de Echenique, B. I. 1980. Population dynamics of Xanthomonas citri causing cancrosis of citrus in Argentina. Proc. Fla. State Hortic. Soc. 93:10-14.

27. Stall, R. E., Miller, J. W., Marco, G. M., and Canteros de Echenique, B. I. 1982. Timing of sprays to control cancrosis of grapefruit in Argentina. Proc. Int. Soc. Citric. 1:414-417.

28. Stein, B., Ramallo, J., Foguet, L., and Graham, J. H. 2007. Citrus leaf miner control and copper fungicide sprays for management of citrus canker on lemon in Tucumán, Argentina. Proc. Fla. State Hortic. Soc. 120:127-131.

29. Sur, R., and Stork, A. 2003. Uptake, translocation and metabolism of imidacloprid in plants. Bull. Insectol. 56:35-40.

30. Tally, A., Oostendorp, M., Lawtion, K., Staub, T., and Bassi, B. 1999. Commercial development of elicitors of induced resistance to pathogens. Pages 357-370 in: Induced Plant Defenses Against Pathogens and Herbivores. Biochemistry, Ecology, and Agriculture. A. A. Agrawal, S. Tuzun, and E. Bent, eds. American Phytopathological Society, St. Paul, MN.

31. Timmer, L. W. 1988. Evaluation of bactericides for control of citrus canker in Argentina. Proc. Fla. State Hortic. Soc. 101:6-9.

32. Vallad, G. E., and Goodman, R. M. 2004. Systemic acquired resistance and induced systemic resistance in conventional agriculture. Crop Sci. 44:19201934.

33. van Loon, L. C., Rep, M., and Pieterse, C. M. J. 2006. Significance of inducible defense-related proteins in infected plants. Annu. Rev. Phytopathol. 44:135-162.

34. Walters, D. R., and Fountaine, J. M. 2009. Practical application of induced resistance to plant diseases: an appraisal of effectiveness under field conditions. J. Agric. Sci. 147:523-535. 